Michał Rogoi

Instyłut Informacii Naukowej i Bibliotekoznawstwa Uniwersytet Pedagogiczny im. Komisji Edukacii Narodowej w Krakowie e-mail: mrogoz@up.krakow.pl

\title{
Książki Janusza Korczaka na polskim rynku wydawniczym
}

DOI: $10.12775 /$ TSB.2013.003

STRESZCZENIE: W artykule scharakteryzowano rozwój ruchu wydawniczego związanego ze spuścizną literacką Janusza Korczaka od pierwszej samodzielnej publikacji książkowej w 1901 r. po czasy obecne (2011 r.). W analizie uwzględniono wszystkie druki samoistne wydane na terenie Polski w wyżej wymienionym okresie (także powstałe przed II wojną światową tłumaczenia na język jidysz) oraz książki wydawane poza granicami kraju w języku polskim. Skupiono się na szeregu aspektów związanych z prezentacją spuścizny wydawniczej, takich jak publikacja pierwodruków, zasięg geograficzny i instytucjonalny, periodyzacja oraz niektóre cechy bibliologiczne, np. przynależność do serii, szata graficzna oraz komentarze i opracowania autorskie. Odmienna liczba edycji poszczególnych tytułów w wyróżnionych okresach wskazywała na zmieniającą się popularność pewnych treści, co było wynikiem zarówno określonej polityki wydawniczej w czasach Polski Ludowej, jak i przemian światopoglądowych i społecznych wpływających na recepcję utworów J. Korczaka po 1989 r.

SŁOWA KLUCZOWE: edytorstwo, Korczak Janusz, recepcja wydawnicza, statystyka wydawnicza.

\section{Wprowadzenie}

enryk Goldszmit, piszący pod pseudonimem Janusz Korczak, był jednym z najwybitniejszych przedstawicieli światowej myśli pedago- 
gicznej, humanistą znanym nie tylko ze swoich rozważań teoretycznych na temat wychowania młodego pokolenia, ale przede wszystkim z wieloletniej praktyki zdobytej w trakcie prowadzenia sierocińców i domów opieki dla dzieci. Recepcja jego idei w różnych krajach następowała wielotorowo w zależności od lokalnych obyczajów, tradycji i potrzeb. Również w Polsce można wyróżnić w tym względzie kilka charakterystycznych okresów ${ }^{1}$.

Dorobek piśmienniczy J. Korczaka charakteryzuje się bardzo dużą różnorodnością tematyczną i gatunkową, która jest wypadkową jego szerokich zainteresowań oraz niełatwych losów życia zakończonych heroiczną śmiercią w obozie zagłady w Treblince ${ }^{2}$. Tworzył on zarówno teksty naukowe, popularnonaukowe i publicystyczne poświęcone metodyce pracy pedagogicznej, psychologii dziecka, medycynie, życiu społecznemu oraz szerszym zagadnieniom humanistycznym, jak i liczne utwory prozatorskie - nowele, powieści, a nawet dramaty ${ }^{3}$. Wiele $\mathrm{z}$ tych dzieł zawierało wyraźne ślady indywidualnych doświadczeń; należy przywołać w tym miejscu wstrząsający pamiętnik z warszawskiego getta ${ }^{4}$ czy też zbiór modlitw Sam na sam z Bogiem ${ }^{5}$. Oprócz tematów poważnych w jego spuściźnie znajdują się także zabawne humoreski opublikowane w zbiorze Koszałki opałki (Warszawa 1905) oraz cykl radiowych pogadanek udostępnionych czytelnikowi w ostatniej przedwojennej publikacji Pedagogika żartobliwa (Warszawa 1939). Janusz Korczak powszechnie jest kojarzony przede wszystkim jako autor popularnych powieści dla dzieci i młodzieży o królu Maciusiu - Król Maciuś Pierwszy (Warszawa 1923) i Król Maciuś na bezludnej wyspie (Warszawa 1923), o szkolnym „biznesmenie” Dżeku - Bankructwo małego Dżeka (Warszawa 1924) czy

1 Zagadnienie recepcji myśli korczakowskiej omawia A. Lewin, Korczak znany i nieznany, Warszawa 1999, s. 337-390.

${ }^{2}$ Za motto jego nienapisanej autobiografii Joanna Olczak-Ronikier uznała zdanie z Pamiętnika mówiące o tym, że „jego życie było trudne, ale ciekawe - o takie właśnie prosił Boga w młodości". Por. J. Olczak-Ronikier, Korczak. Próba biografii, Warszawa 2011, s. 9.

${ }^{3}$ W wersji drukowanej ukazał się jedynie scenariusz teatralny trzyaktówki Senat szaleńców. Inne teksty sceniczne J. Korczaka nie zachowały się. Por. M. Falkowska, Kalendarz życia, działalności i twórczości Janusza Korczaka, Warszawa 1989, s. 258.

${ }^{4}$ Po raz pierwszy wydany w Polsce w czwartym tomie Wyboru pism (Warszawa 1958) poprzedzonym wstępem Igora Newerlego, który stał się powiernikiem tego cennego dokumentu.

${ }^{5}$ J. Korczak, Sam na sam z Bogiem. Modlitwy tych, którzy się nie modlq, Warszawa 1922. 
o mającym magiczną moc Kajtusiu - Kajtuś Czarodziej (Warszawa 1934). Wiele z jego utworów przeznaczonych pozornie tylko dla młodego odbiorcy zawierało przesłanie skierowane do dorosłych ${ }^{6}$. Wrażliwość na problemy wychowawcze oraz społeczne losy dziecka odzwierciedliła się także w literackiej twórczości adresowanej do dojrzałego czytelnika. Należy tu wymienić m.in. wczesne powieści Dzieci ulicy (Warszawa 1901) i Dziecko salonu (Warszawa 1906), które Teresa Walas łączy z kręgiem późnej literatury modernistycznej ${ }^{7}$. Na różnorodność literackich zainteresowań urodzonego w Warszawie pisarza wpłynął z pewnością jego rodowód. Wiele utworów zawierało elementy autobiograficzne, część z nich odnosiła się do wątków bezpośrednio związanych z kulturą judaistyczną. W latach 1934 i 1936 J. Korczak przebywał w Palestynie, utrzymywał też liczne kontakty z przyjaciółmi, którzy wyemigrowali do Ziemi Obiecanej. Efektem tych doświadczeń były dwa opowiadania powiązane tematycznie z podróżą do Izraela (Trzy wyprawy Herszka, Ludzie sq dobrzy), a także zbiór listów i esejów wydanych wspólnie dopiero w końcu XX w. - Listy i rozmyślania palestyńskie (Warszawa 1999).

Dotychczasowa spuścizna wydawnicza J. Korczaka była przynajmniej kilkukrotnie przedmiotem opracowań bibliograficznych. W latach 60 . i 70. takie cząstkowe zestawienia ukazywały się w czasopismach pedagogicznych wraz z artykułami poświęconymi jego działalności edukacyjnej i wychowawczej ${ }^{8}$. Z okazji setnej rocznicy urodzin H. Goldszmita ukazała się praca Marii Bronikowskiej notująca wszystkie druki zwarte

${ }^{6}$ Ten stan rzeczy dobitnie potwierdza dedykacja do jednej z jego powieści „,- Nuży nas obcowanie z dziećmi. / Macie słuszność. [...] / - Bo musimy się zniżać do ich pojęć. Zniżać, pochylać, naginać, kurczyć. / Mylicie się. / Nie to nas męczy. Ale, że musimy się wspinać do ich uczuć. / Wspinać, wyciągać na palcach, stawać, sięgać. Żeby nie urazić”. Por. J. Korczak, Kiedy znów będę mały, Warszawa 1983, s. 4.

7 T. Walas, Posłowie, [w:] J. Korczak, Dziecko salonu, Kraków 1980, s. 237-262.

${ }_{8}$ Por. M. Jakubowski, Bibliografia prac poświęconych Januszowi Korczakowi w okresie powojennym, „Ruch Pedagogiczny” 1962, nr 5, s. 96-97; tenże, Zagadnienie samowychowawczej aktywności dziecka w ujęciu Janusza Korczaka (wraz z bibliografią), „Psychologia Wychowawcza" 1962, nr 4, s. 375-391; /bwo/, Przegląd wydawnictw korczakowskich, „Problemy Opiekuńczo-Wychowawcze” 1962, nr 8, s. 36-37; M. Temkin, Książki i artykuły o doktorze Januszu Korczaku (wybór), „Nowa Szkoła” 1967, nr 7/8, s. 29-30; J. A. Igielski, Stan dokumentacji archiwalnej spuścizny Janusza Korczaka, „Przegląd Pedagogiczny” 1974, nr 1, s. 167-171. 
wydane w Polsce w latach 1899-1978, a także dodatkowo wydania zbiorowe z Polski i innych krajów ${ }^{9}$. Równie cennym opracowaniem jest poradnik autorstwa Janiny Huppenthal ze wstępem Witolda Stankiewicza prezentujący najważniejsze utwory oraz teksty ulotne wraz z ich krótkim omówieniem ${ }^{10}$. Przeznaczone do użytku wewnętrznego zestawienie Jadwigi Bieńkowskiej, przygotowane pod auspicjami Wojewódzkiej Biblioteki Publicznej im. T. Mikulskiego we Wrocławiu, rejestruje pierwodruki i wybrane powojenne wydawnictwa zwarte autorstwa J. Korczaka oraz obszerną literaturę przedmiotu ${ }^{11}$. Najpełniejsze, jak dotąd, opracowanie bibliograficzne ukazało się pod redakcją Aleksandra Lewina i obejmuje lata 1896-1942 (t. 1) oraz 1943-1987 (t. 2) ${ }^{12}$. Jako źródło informacji bibliograficznej duże znaczenie ma opracowany przez Marię Falkowską Kalendarz życia, działalności i twórczości Janusza Korczaka (Warszawa 1989), przytaczający m.in. pierwsze recenzje ukazujących się drukiem utworów oraz zestawiający noty biograficzne pochodzące z rozmaitych leksykonów. Ponadto wartościowe kryptobibliografie były dołączane do licznych dzieł związanych z postacią J. Korczaka ${ }^{13}$.

Wobec szerokiego rozpoznania zagadnienia celem niniejszego artykułu jest po pierwsze aktualizacja statystycznego obrazu obecności tej twórczości na polskim ryku wydawniczym, ponieważ wszystkie przytoczone powyżej zestawienia nie uwzględniały edycji z okresu III Rzeczypospolitej. Po drugie, z uwagi na fakt, że opracowania bibliograficzne pełniły przede wszystkim funkcję ewidencyjną, podczas gdy dzieje edycji książek J. Korczaka stanowią specyficzne zjawisko możliwe do opisania w kategoriach bibliologicznych, postanowiono wypełnić istniejącą w tym zakresie lukę, dokonując charakterystyki dotychczasowego dorobku wydawniczego. Zwrócono uwagę na czas i miejsce wydania poszczególnych

${ }^{9}$ Zamieszczono tu także wykaz tytułów przedwojennych czasopism publikujących jego artykuły. Por. M. Bronikowska, Bibliografia prac Janusza Korczaka, Warszawa 1978.

10 J. Huppenthal, Janusz Korczak, Warszawa 1978.

11 Janusz Korczak 1878-1942. Materiały bibliograficzne, wyb. i oprac. J. Bieńkowska, Wrocław 1978.

12 Janusz Korczak. Bibliografia 1896-1942, pod red. A. Lewina, Heinsberg 1985; Janusz Korczak. Bibliografia publikacji Janusza Korczaka i o Januszu Korczaku w Polsce 1943-1987, pod red. A. Lewina, Heinsberg 1988.

${ }^{13}$ Niektóre woluminy zawierały spisy wydanych dotychczas książek jego autorstwa. Por. J. Korczak, Bezwstydnie krótkie, Warszawa 1926, s. 2; J. Olczak-Ronikier, dz. cyt., s. 435-439. 
edycji, w tym zmieniającą się popularność poszczególnych utworów, specyfikę poszczególnych edycji, autorstwo dołączanych komentarzy i ilustracji oraz inne istotne aspekty związane z obecnością twórczości J. Korczaka na polskim rynku książki. W przeprowadzonych analizach uwzględniono wszystkie druki zwarte, które ukazały się na terytorium Polski do końca grudnia 2011 r. Dodatkowo kwerendą objęto trzy pozycje emigracyjne $\mathrm{w}$ języku polskim wydane $\mathrm{w}$ okresie okupacji na potrzeby rodaków przebywających wraz z polskim wojskiem w Jerozolimie oraz w Wielkiej Brytanii.

\section{Pierwodruki}

Drukowane teksty H. Goldszmita pojawiały się od 1896 r. w piśmie satyrycznym „Kolce” i były sygnowane kilkoma pseudonimami (m.in. Hen., Janusz, Hagot, G). W tym wczesnym okresie twórczości powstał też dramat Którędy?, wyróżniony w konkursie literackim zorganizowanym pod patronatem Ignacego Paderewskiego. Tekst ten nie zachował się do dzisiaj, jego treść znamy jedynie z recenzji ${ }^{14}$. Debiutem na rynku książki była powieść Dzieci ulicy wydana w 1901 r. przez Aleksandra Pajewskiego, właściciela wspomnianego już czasopisma „Kolce”. Utwór ten ukazał się pod pseudonimem artystycznym „Janusz Korczak”, któremu pisarz zasadniczo pozostał wierny do końca życia ${ }^{15}$.

W tabeli 1 zestawiono pierwsze wydania ważniejszych utworów J. Korczaka, ukazując etapy jego twórczej działalności. Większość pozycji to druki samoistne, jednak, zwłaszcza w przypadku dzieł o charakterze publicystycznym, wydawcy stosowali często zwyczaj łączenia kilku oddzielnych utworów w jednym woluminie. Nie uwzględniono tu bardzo licznej grupy artykułów prasowych czy listów, które w wersji książkowej

14 M. Falkowska, dz. cyt., s. 58-59.

15 Pewien wyjątek w tym zakresie stanowią opublikowane rok później króciutkie powiastki i wierszyki dla dzieci podpisane "Janusz” oraz oba wydania humoresek Koszałki opałki, w których umieszczonemu w nawiasie pseudonimowi "Janusz Korczak" towarzyszy jeszcze jeden: „Hen-ryk”. Właściwym imieniem i nazwiskiem były natomiast oznaczane niektóre artykuły z dziedziny medycyny. Historię powstania pseudonimu „Janusz Korczak" wyjaśnia m.in. Igor Newerly. Por. I. Newerly, Wstęp, [w:] J. Korczak, Wybór pism, t. 1, Warszawa 1957, s. XI. 
były publikowane po raz pierwszy dopiero w powojennych edycjach jego dzieł. Warto przy tym zauważyć, że pewna część dorobku zaginęła, niektóre utwory są znane tylko z tłumaczeń na języki obce (hebrajski lub jidysz), inne zaś zachowały się jedynie w formie mniej lub bardziej wiernych odpisów. Osobną grupę stanowią wywiady i zapisane przez współpracowników lub uczniów krótkie wypowiedzi ustne ${ }^{16}$.

Tabela 1. Zestawienie pierwodruków ważniejszych utworów Janusza Korczaka w języku polskim

\begin{tabular}{|c|c|c|c|}
\hline Tytuł & Rok wydania & $\begin{array}{l}\text { Miejsce } \\
\text { wydania }\end{array}$ & Wydawnictwo \\
\hline Dzieci ulicy & 1901 & Warszawa & T. Pajewski \\
\hline Króciutkie powiastki ${ }^{17}$ & 1902 & Warszawa & J. Guranowski \\
\hline Tylko dla grzecznych dzieci ${ }^{18}$ & 1902 & Warszawa & J. Guranowski \\
\hline Koszałki opałki & 1905 & Warszawa & Księgarnia Powszechna \\
\hline Dziecko salonu & 1906 & Warszawa & Księgarnia Powszechna \\
\hline Mośki, Joski i Srule & $1909(1910)^{19}$ & Warszawa & Centnerszwer i s-ka \\
\hline Józki, Jaśki i Franki & $1910(1911)$ & Warszawa & Centnerszwer i s-ka \\
\hline Sława & 1912 (1913) & Warszawa & Centnerszwer i s-ka \\
\hline $\begin{array}{l}\text { Bobo, Feralny tydzień, } \\
\text { Spowiedź motyla }{ }^{20}\end{array}$ & $1913(1914)$ & Warszawa & Centnerszwer i s-ka \\
\hline $\begin{array}{l}\text { Jak kochać dziecko, Dziecko } \\
\text { w rodzinie }\end{array}$ & 1918 (1919) & Warszawa & TW Mortkowicz \\
\hline Momenty wychowawcze & 1919 & Warszawa & Książka Polska \\
\hline
\end{tabular}

16 Por. M. Ciesielska, Charakterystyka spuścizny pisarskiej Janusza Korczaka, [w:] Janusz Korczak. Bibliografia 1896-1942, pod red. A. Lewina, Heinsberg 1985, s. 19. Przykładem tego typu pozycji powstałej przy udziale kilku wychowawców z Domu Dziecka są wydane w 1924 r. przez Spółdzielnię Wydawniczą „Książka” Wspomnienia z maleńkości Naszego Domu w Pruszkowie.

17 Pozycje niedostępne. Opis bibliograficzny przytoczony za: Janusz Korczak. Bibliografia..., t. 1, s. 94.

${ }_{18}$ Por. przypis 13.

19 Pozycje postdatowane: poza nawiasem podano rok ukazania się drukiem, w nawiasie rok podany na stronie tytułowej.

20 Trzy teksty ukazały się w jednym woluminie pod tytułem Bobo. 
Tabela 1. Zestawienie pierwodruków (cd.)

\begin{tabular}{|l|l|l|l|}
\hline \multicolumn{1}{|c|}{ Tytuł } & Rok wydania & $\begin{array}{c}\text { Miejsce } \\
\text { wydania }\end{array}$ & \multicolumn{1}{|c|}{ Wydawnictwo } \\
\hline $\begin{array}{l}\text { Internat, Kolonie letnie, Dom } \\
\text { Sierot }{ }^{21}\end{array}$ & 1920 & Warszawa & TW Mortkowicz \\
\hline O gazetce szkolnej & 1921 & Warszawa & $\begin{array}{l}\text { Polska Składnica } \\
\text { Pomocy Szkolnych }\end{array}$ \\
\hline Sam na sam z Bogiem & $1921(1922)$ & Warszawa & TW Mortkowicz \\
\hline Król Maciuś Pierwszy & $1922(1923)$ & Warszawa & TW Mortkowicz \\
\hline $\begin{array}{l}\text { Król Maciuś na wyspie } \\
\text { bezludnej }\end{array}$ & 1923 & Warszawa & TW Mortkowicz \\
\hline Bankructwo małego Dżeka & 1924 & Warszawa & TW Mortkowicz \\
\hline Kiedy znów będę mały & 1925 & Warszawa & TW Mortkowicz \\
\hline Bezwstydnie krótkie & 1926 & Warszawa & TW Mortkowicz \\
\hline Prawo dziecka do szacunku & $1928(1929)$ & Warszawa & TW Mortkowicz \\
\hline Prawidła życia & $1929(1930)$ & Warszawa & TW Mortkowicz \\
\hline Kajtuś Czarodziej & $1934(1935)$ & Warszawa & TW Mortkowicz \\
\hline $\begin{array}{l}\text { Uparty chłopiec. Źycie } \\
\text { Ludwika Pasteura }\end{array}$ & 1938 & Warszawa & TW Mortkowicz \\
\hline Ludzie sq dobrzy & 1938 & Warszawa & Keren Kajemet Leisrael \\
\hline Refleksje & 1938 & Warszawa & $\begin{array}{l}\text { Towarzystwo „Pomoc } \\
\text { dla Sierot” }\end{array}$ \\
\hline Trzy wyprawy Herszka & 1939 & Warszawa & Keren Kajemet Leisrael \\
\hline Pedagogika żartobliwa & 1939 & Warszawa & TW Mortkowicz \\
\hline Pamiętnik ${ }^{22}$ & 1984 & $\begin{array}{l}\text { Wydawnictwo } \\
\text { Poznańskie }\end{array}$ \\
\hline
\end{tabular}

Źródło: opracowanie własne na podstawie: M. Bronikowska, Bibliografia prac Janusza Korczaka, Warszawa 1978; Korczak. Bibliografia 1896-1942, pod red. A. Lewina, Heinsberg 1985.

${ }^{21}$ Teksty ukazały się w trzytomowym wydaniu pt. Jak kochać dziecko zawierającym dodatkowo publikowany już wcześniej szkic Dziecko w rodzinie.

${ }^{22}$ Edycja pośmiertna. Pierwsze wydanie samodzielne. Po raz pierwszy tekst pamiętnika zamieszczono w czwartym tomie Wyboru pism, Warszawa 1958. 
W latach 1918-1921 ukazały się pierwsze zbiory prac pedagogicznych, które były wynikiem kilkuletniej praktyki związanej z działaniem Domu Sierot na ul. Krochmalnej w Warszawie ${ }^{23}$. Kolejne tego typu opracowania opublikowane w latach 1928-1929 stanowiły swoisty manifest praw dziecka. Niektóre miały charakter edukacyjny i przybierały formę niewielkich broszur, jak np. opublikowany nakładem Polskiej Składnicy Pomocy Szkolnych artykuł o prowadzeniu klasowej gazetki (1921 r.) czy równie krótkie refleksje pedagogiczne wydane przez towarzystwo dobroczynne „Pomoc dla Sierot”. Apogeum twórczej działalności J. Korczaka przypada na lata 20. kiedy to ukazało się drukiem kilkanaście najważniejszych w jego dorobku piśmienniczym pozycji, w tym najbardziej znana dylogia dziecięca o królu Maciusiu Pierwszym oraz równie popularna opowieść o założycielu szkolnej spółdzielni Dżeku Fultonie.

Janusz Korczak współpracował przede wszystkim z warszawskimi wydawcami ${ }^{24}$. Najwięcej debiutów firmowało Towarzystwo Wydawnicze Jakuba Mortkowicza. Niektóre edycje ukazujące się w tej oficynie były ze względów marketingowych postdatowane ${ }^{25}$.

\section{Edycie utworów Janusza Korczaka}

W okresie ponad stu lat od debiutu wydawniczego ukazało się ponad 200 woluminów dzieł J. Korczaka, w tym ponad 40 książek ${ }^{26}$, które opublikowano jeszcze za życia autora. Ten dorobek można podzielić pod względem tematycznym na kilka grup: teksty o charakterze beletrystycznym, teksty publicystyczne oraz kompilacje. Osobne zagadnienie stanowią też nieliczne utwory w języku jidysz wydane w przedwojennej Polsce. Przed 1942 r. wznowiono łącznie 17 jego utworów beletrystycznych (tabela 2). Powtórnego wydania nie doczekały się w tym czasie m.in. debiutancka

${ }^{23}$ Por. J. Olczak-Ronikier, dz. cyt., s. 188-194.

24 J. Olczak-Ronikier podkreśla ten warszawski patriotyzm Korczaka, przytaczając wyjątki z jego późniejszego pamiętnika, w tym polemikę z pewnym narodowcem. Tamże, s. 191.

25 Informacja umieszczona w stopce redakcyjnej lub na frontispisie przesuwała właściwą datę wydania o jeden rok do przodu (por. tabela 1). Dzięki temu książka dłużej pozostawała nowością wydawniczą.

${ }^{26}$ Uwzględniając kolejne ich edycje. 
powieść Dzieci ulicy, powiastki Bobo i Spowiedź motyla, kilka krótszych utworów oraz, co zrozumiałe, późne teksty powstałe w latach 30. Najczęściej wydawaną książką za życia J. Korczaka była powieść Sława ${ }^{27}$.

Po 1945 r. nie pojawiły się samoistne wydawniczo wznowienia popularnej przed 1939 r. opowieści wakacyjnej z życia żydowskich dzieci Mośki, Joski i Srule, której tytuł brzmi znacznie lepiej w języku hebrajskim Moyshelekh, Yoselekh, Yisrolikelekh. Niemniej jednak w 1946 r. ukazała się książka Na koloniach letnich, w której umieszczono wspomniany tekst wraz z bliźniaczym utworem Józki, Jaśki i Franki ${ }^{28}$. W edycji tej pominięto zawarte w oryginałach przedwojennych załączniki w postaci szkicu fortów bronionych przez generała Hersza Korcarza oraz obozu Miłosny w lesie Wilhelmówka. O ile powieść Józki, Jaśki, Franki została wznowiona jeszcze raz w połowie lat 80. na fali popularności opowiadań harcerskich ${ }^{29}$, o tyle jej starszy odpowiednik ze względu na odmienny kontekst społeczny stał się dziełem przypominanym jedynie przy okazji edycji dzieł zebranych.

Tabela 2. Liczba polskich wydań wybranych utworów beletrystycznych Janusza Korczaka (uwzględniono też teksty opublikowane w opracowaniach zbiorowych)

\begin{tabular}{|l|c|c|c|c|c|c|}
\hline \multirow{2}{*}{ Tytuł utworu } & \multicolumn{7}{|c|}{ Liczba wydań } \\
\cline { 2 - 7 } & $\begin{array}{c}\text { do } \\
1918\end{array}$ & $\begin{array}{c}\text { dwudziestolecie } \\
\text { międzywojenne }\end{array}$ & $\begin{array}{c}\text { od 1939 } \\
\text { do } 1989\end{array}$ & $\begin{array}{c}\text { od 1990 } \\
\text { do 2011 }\end{array}$ & ogółem & $\begin{array}{c}\text { w tym } \\
\text { dziełach } \\
\text { zebranych }\end{array}$ \\
\hline $\begin{array}{l}\text { Bankructwo } \\
\text { małego Dżeka }\end{array}$ & - & 3 & 8 & 2 & 13 & 1 \\
\hline $\begin{array}{l}\text { Bezwstydnie } \\
\text { krótkie }\end{array}$ & - & 1 & 1 & 2 & 4 & 2 \\
\hline Bobo & 1 & - & 3 & 1 & 5 & 2 \\
\hline
\end{tabular}

27 Kolejne edycje ukazywały się w latach 1912 (postdatowane na 1913), 1925, 1937, a także w 1927 r. w przeróbce scenicznej Jadwigi Borowicz. Ostatnie samodzielne wydanie Sławy ukazało się w 1958 r., ponownie tekst ten został opublikowany dopiero w 1996 r. w szóstym tomie Dzieł zebranych.

${ }^{28}$ J. Korczak, Na koloniach letnich, Warszawa 1946.

29 Oparta na wydaniu z 1922 r. kieszonkowa edycja Krajowej Agencji Wydawniczej z 1985 r. pełniła nawet funkcję szkolnej lektury obowiązkowej dla IV klasy szkoły podstawowej.

${ }^{30}$ Nie uwzględniano publikacji fragmentarycznych. 
Tabela 2. Liczba polskich wydań wybranych utworów beletrystycznych (cd.)

\begin{tabular}{|c|c|c|c|c|c|c|}
\hline \multirow[b]{2}{*}{ Tytuł utworu } & \multicolumn{6}{|c|}{ Liczba wydań } \\
\hline & $\begin{array}{c}\text { do } \\
1918\end{array}$ & $\begin{array}{l}\text { dwudziestolecie } \\
\text { międzywojenne }\end{array}$ & $\begin{array}{l}\text { od } 1939 \\
\text { do } 1989\end{array}$ & $\begin{array}{l}\text { od } 1990 \\
\text { do } 2011\end{array}$ & ogółem & $\begin{array}{c}\text { w tym } \\
\text { w dziełach } \\
\text { zebranych }\end{array}$ \\
\hline Dzieci ulicy & 1 & - & - & 1 & 2 & 1 \\
\hline Dziecko salonu & 1 & 1 & 4 & 1 & 7 & 4 \\
\hline Feralny tydzień & 1 & 2 & 2 & 1 & 6 & 3 \\
\hline Koszałki opałki & 2 & - & 1 & 1 & 4 & 2 \\
\hline $\begin{array}{l}\text { Józki, Jaśki } \\
\text { i Franki }\end{array}$ & 1 & 3 & 4 & 1 & 9 & 2 \\
\hline $\begin{array}{l}\text { Kajtuś } \\
\text { Czarodziej }\end{array}$ & - & 1 & 6 & 8 & 15 & 1 \\
\hline $\begin{array}{l}\text { Kiedy znów } \\
\text { będę mały }\end{array}$ & - & 1 & 5 & 2 & 8 & 4 \\
\hline $\begin{array}{l}\text { Król Maciuś } \\
\text { Pierwszy }\end{array}$ & - & 2 & 12 & 52 & 66 & 1 \\
\hline $\begin{array}{l}\text { Król Maciuś } \\
\text { na wyspie } \\
\text { bezludnej }\end{array}$ & - & 2 & 9 & 8 & 19 & 1 \\
\hline $\begin{array}{l}\text { Ludzie sq } \\
\text { dobrzy }\end{array}$ & - & 1 & - & 1 & 2 & 1 \\
\hline $\begin{array}{l}\text { Mośki, Joski } \\
\text { i Srule }\end{array}$ & 1 & 3 & 2 & 1 & 7 & 3 \\
\hline Pamiętnik & - & - & 4 & 1 & 5 & 3 \\
\hline $\begin{array}{l}\text { Sam na sam } \\
\text { z Bogiem }\end{array}$ & - & 1 & 2 & 4 & 7 & 3 \\
\hline $\begin{array}{l}\text { Senat } \\
\text { szaleńców }\end{array}$ & - & - & 1 & 1 & 2 & 2 \\
\hline Sława & 1 & 4 & 4 & 1 & 10 & 1 \\
\hline $\begin{array}{l}\text { Spowiedź } \\
\text { motyla }\end{array}$ & 1 & & 1 & 1 & 3 & 2 \\
\hline
\end{tabular}

31 Dramat, którego premiera odbyła się 1 października 1931 r. w warszawskim teatrze „Ateneum”, jego scenariusz został opublikowany dopiero po wojnie i tylko w zbiorczych edycjach dzieł J. Korczaka. Por. M. Falkowska, dz. cyt., s. 258. 
Tabela 2. Liczba polskich wydań wybranych utworów beletrystycznych (cd.)

\begin{tabular}{|l|c|c|c|c|c|c|}
\hline \multirow{2}{*}{ Tytuł utworu } & \multicolumn{7}{|c|}{ Liczba wydań } \\
\cline { 2 - 7 } & $\begin{array}{c}\text { do } \\
1918\end{array}$ & $\begin{array}{l}\text { dwudziestolecie } \\
\text { międzywojenne }\end{array}$ & $\begin{array}{c}\text { od 1939 } \\
\text { do } 1989\end{array}$ & $\begin{array}{c}\text { od 1990 } \\
\text { do 2011 }\end{array}$ & ogółem & $\begin{array}{c}\text { w tym } \\
\text { w dziełach } \\
\text { zebranych }\end{array}$ \\
\hline Szkoła życia ${ }^{32}$ & - & - & 3 & 1 & 4 & 4 \\
\hline $\begin{array}{l}\text { Trzy wyprawy } \\
\text { Herszka }\end{array}$ & - & 1 & - & 1 & 2 & 1 \\
\hline $\begin{array}{l}\text { Uparty } \\
\text { chłopiec. } \\
\begin{array}{l}\text { Zycie Ludwika } \\
\text { Pasteura }\end{array}\end{array}$ & - & 1 & 1 & 1 & 3 & 1 \\
\hline
\end{tabular}

Źródło: opracowanie własne na podstawie: Janusz Korczak. Bibliografia 1896-1942 , pod red. A. Lewina, Heinsberg 1985; Janusz Korczak. Bibliografia publikacji Janusza Korczaka i o Januszu Korczaku w Polsce 1943-1987, pod red. A. Lewina, Heinsberg 1988; „Przewodnik Bibliograficzny” za lata 1988-2011; Narodowy Uniwersalny Katalog Biblioteczny; Katalog Rozproszony Bibliotek Polskich.

W okresie powojennym nastąpił wyraźny wzrost zainteresowania twórczością Starego Doktora. Edycja poszczególnych dzieł podlegała fluktuacjom wynikającym zarówno ze zmian oficjalnej doktryny polityczno-społecznej w kraju, jak i głębszych przemian kulturowych. Wydaje się, że po 1945 r. J. Korczak był promowany głównie jako pisarz dziecięcy. Nic więc dziwnego, że do tej pory książką najczęściej wznawianą jest powieść Król Maciuś Pierwszy (tabela 2), której popularność szczególnie wzrosła w czasach najnowszych (po 1989 r.), o czym świadczy duża liczba edycji ${ }^{33}$ oraz opracowanie wersji dźwiękowej ${ }^{34}$. Warto zaznaczyć, że mimo obowiązującej jeszcze klauzuli o ochronie praw autorskich na-

32 Powieść utopijna wydrukowana w latach 1907-1908 na łamach „Przeglądu Społecznego”. Nigdy nie doczekała się osobnej edycji książkowej, a jedyne istniejące wydania znajdują się w zbiorczych tomach dzieł. Por. tamże, s. 110-111.

${ }_{33}$ Z danych Biblioteki Narodowej wynika, że łączny nakład wszystkich wydań powieści Król Maciuś Pierwszy w latach 1944-2011 przekroczył milion egzemplarzy. Por. „Ruch Wydawniczy w Liczbach” 2011, s. 138, tab. 42.

34 Obie części dylogii ukazały się w 2011 r. na płytach CD w Bibliotece Akustycznej Wydawnictwa WAB. Tekst czyta Krzysztof Tyniec. 
kazującej wnoszenie stosownych opłat na rzecz Instytutu Książki, edycją tego utworu w ostatnich dekadach zainteresowała się rekordowa liczba oficyn, całkowicie przełamany został w tym względzie charakterystyczny dla okresu PRL monopol „Naszej Księgarni”. Uwagę zwraca zróżnicowana jakość poszczególnych wydań. W niektórych zabrakło charakterystycznego zdjęcia młodego Korczaka, które stanowiło jakby punkt wyjścia utworu $^{35}$ (m.in. nie ma go w książce Wydawnictwa „Klasyka”). Stosowano też odmienną pisownię tytułu - w niektórych przypadkach wprowadzając zapis liczebnika cyfrą rzymską (np. Podsiedlik, Raniowski i s-ka). Druga część cyklu powieściowego Król Maciuś na bezludnej wyspie, która nie należała do kanonu lektur szkolnych, cieszyła się znacznie mniejszym zainteresowaniem wydawców. Po 1989 r. na edycję obu wymienionych tytułów zdecydowały się tylko cztery firmy: Res Polona, Beskidzka Oficyna Wydawnicza, Zielona Sowa i WAB. Kontynuacja przygód małego króla nie była więc utworem tak mocno rozpowszechnionym w świadomości społecznej, nie stała się jak do tej pory przedmiotem ekranizacji, stąd też zapewne nie została przez wydawców doceniona jako ważne dopełnienie wymowy całej dylogii. Oprócz tych dwóch tytułów, trzecim najczęściej wydawanym dziełem beletrystycznym Starego Doktora była powieść Kajtuś Czarodziej, która w okresie powojennym doczekała się 14 edycji (por. tabela 2), zróżnicowanych pod względem formatu, ilustracji oraz dodatków (np. skierowane do dziecięcego odbiorcy posłowie Wiktora Woroszylskiego). Wstępy do utworów dziecięcych pojawiały się głównie w okresie PRL. Miały wpływać na recepcję według ustalonego z góry schematu światopoglądowego, ich obecność wynikała także z faktu, że były to lektury szkolne omawiane na lekcjach języka polskiego. W ostatnich latach za interesujące przedsięwzięcie popularyzatorskie należy uznać wydania wspólne krakowskiej oficyny Zielona Sowa oraz agencji Polskapresse, rozpowszechniane jako dodatki do dzienników regionalnych, m.in. „Gazety Krakowskiej” i „Głosu Wielkopolskiego" ${ }^{36}$. Nieco mniejszym zainteresowaniem wydawców, zwłaszcza w pierwszej dekadzie XXI w., cieszy się powieść Bankructwo małego Dżeka. Tytuł ten był szczególnie popularyzowany w okresie Polski Ludowej (do połowy lat 60.). Rzecz

35 M. Chrobak, Niespokojni chłopcy Korczaka, „Konspekt” 2012, nr 3, s. 63.

${ }^{36}$ Wydania Króla Maciusia Pierwszego, Króla Maciusia na wyspie bezludnej i Kajtusia Czarodzieja. 
ciekawa, że oparta na faktach i mająca optymistyczny wydźwięk opowieść biograficzna Uparty chłopiec. Życie Ludwika Pasteura poza swoim pierwodrukiem (1938 r.) doczekała się tylko jeszcze jednego samoistnego wydania w 1960 r. $^{37}$ Po przemianach ustrojowych w 1989 r. rosnącej dynamice wydawniczej najbardziej znanych utworów J. Korczaka kojarzonych z odbiorcą dziecięcym towarzyszyło stosunkowo mniejsze zainteresowanie innymi jego dziełami ${ }^{38}$. Spośród tekstów częściej wznawianych w ostatnim czasie należy wymienić zbiór modlitw Sam na sam z Bogiem, który po 1989 r. ukazał się dwukrotnie w oficynach katolickich (Wyd. Księży Sercanów, Biblioteka „Więzi”), jak również w Agencji Edytorskiej Ezop ${ }^{39}$. Na duży potencjał ekumeniczny tego tomu zwrócił uwagę m.in. ksiądz Jan Twardowski, autor jednego ze wstępów: „Książka ta jest najbardziej uniwersalna, służebna wobec wszystkich, którzy tęsknią za Bogiem, poróżnionych odmiennymi wyznaniami. Polecamy ją wdzięcznej, cierpliwej ludzkiej pamięci" ${ }^{40}$.

Zdecydowanie najwięcej pojedynczych wydań miały takie utwory publicystyczne, jak Dziecko w rodzinie oraz Prawo dziecka do szacunku (tabela 3). W przypadku prac pedagogicznych znacznie częściej wydawcy stosowali zabieg polegający na łączeniu kilku utworów w jednym woluminie. Skądinąd już pierwsze dzieło pedagogiczne J. Korczaka, Jak kochać dziecko, zostało rozpisane na poszczególne, dopełniające się nawzajem części: Dziecko w rodzinie, Internat, Kolonie letnie, Dom sierot.

Warto zauważyć wyraźną dysproporcję w liczbie wydań Dziecka $w$ rodzinie w stosunku do trzech pozostałych części tak zarysowanej tetralogii w okresie najnowszym, świadczącą o tym, że wszelkie sposoby wychowania uspołecznionego stały się w obecnym świecie mniej istotne wobec problemu funkcjonowania dziecka w obrębie rodziny. Ten cykl rozdzielano także we wcześniejszych wydaniach. Już w latach 20. ukazywał się on w trzech oddzielnych woluminach. W 1948 r. pojawiła się

37 Została także zamieszczona w dziełach zebranych (t. 12, 1998).

38 Ogłoszenie przez Sejm Rzeczypospolitej Polskiej roku 2012 Rokiem Janusza Korczaka może w dalszej perspektywie czasu przyczynić się do zmiany tej sytuacji.

39 Pochodząca z tego tomiku Modlitwa matki została też włączona do zbioru poświęconego tragedii Holocaustu, zawierającego wstrząsający pamiętnik z łódzkiego getta autorstwa Ireny Hauser. Por. I. Hauser, Cud, że ręka jeszcze pisze..., Warszawa 1993, s. 96.

40 J. Twardowski, Posłowie, [w:] J. Korczak, Sam na sam z Bogiem. Modlitwy tych, którzy się nie modlą, Warszawa 1993, s. 79. 
131-stronicowa edycja zawierająca rozdziały Internat i Kolonie letnie, dopełniająca wydaną jeszcze podczas wojny w szkockim Glasgow pozycję Jak kochać dzieci. Dom Sierot, gdzie po raz pierwszy umieszczono wstęp informujący o śmierci J. Korczaka. Drugą najpopularniejszą pracą pedagogiczną był nowatorski, jak na czas swego powstania, manifest praw dziecka Prawo dziecka do szacunku. To krótkie dzieło wznawiano najczęściej w okresie PRL (tabela 3).

Tabela 3. Liczba polskich wydań wybranych utworów publicystycznych Janusza Korczaka (uwzględniono też teksty opublikowane w dziełach zebranych)

\begin{tabular}{|l|c|c|c|c|c|c|}
\hline \multirow{2}{*}{ Tytuł utworu } & \multicolumn{5}{|c|}{ Liczba wydań } \\
\cline { 2 - 7 } & $\begin{array}{c}\text { do } \\
1918\end{array}$ & $\begin{array}{c}\text { od } 1918 \\
\text { do } 1939\end{array}$ & $\begin{array}{c}\text { od 1939 } \\
\text { do } 1989\end{array}$ & $\begin{array}{c}\text { od 1990 } \\
\text { do 2011 }\end{array}$ & ogółem & $\begin{array}{c}\text { w tym } \\
\text { w dziełach } \\
\text { zebranych }\end{array}$ \\
\hline $\begin{array}{l}\text { Jak kochać } \\
\text { dziecko: Dziecko } \\
\text { w rodzinie }\end{array}$ & - & 3 & 7 & 8 & 18 & 5 \\
\hline Internat & - & 2 & 6 & 1 & 9 & 5 \\
\hline Kolonie letnie & - & 2 & 6 & 1 & 9 & 5 \\
\hline Dom sierot & - & 2 & 6 & 1 & 9 & 5 \\
\hline $\begin{array}{l}\text { Listy i rozmyślania } \\
\text { palestyńskie }\end{array}$ & - & - & - & 1 & 1 & - \\
\hline $\begin{array}{l}\text { Momenty } \\
\text { wychowawcze }\end{array}$ & - & 2 & 4 & 1 & 7 & 5 \\
\hline $\begin{array}{l}\text { Myśl pedagogiczna } \\
\text { Janusza Korczaka: } \\
\text { nowe źródła }\end{array}$ & - & - & 1 & - & 1 & - \\
\hline Myśli & - & - & 1 & - & 1 & - \\
\hline O gazetce szkolnej & - & 1 & 4 & 1 & 6 & 5 \\
\hline $\begin{array}{l}\text { Pedagogika } \\
\text { żartobliwa }\end{array}$ & - & 1 & 5 & 1 & 7 & 5 \\
\hline Prawidła życia & - & 1 & 6 & 1 & 8 & 5 \\
\hline
\end{tabular}

41 Bez uwzględnienia publikowanych fragmentów poszczególnych utworów. 
Tabela 3. Liczba polskich wydań wybranych utworów publicystycznych (cd.)

\begin{tabular}{|l|c|c|c|c|c|c|}
\hline \multirow{2}{*}{ Tytuł utworu } & \multicolumn{7}{|c|}{ Liczba wydań } \\
\cline { 2 - 7 } & $\begin{array}{c}\text { do } \\
1918\end{array}$ & $\begin{array}{c}\text { od 1918 } \\
\text { do 1939 }\end{array}$ & $\begin{array}{c}\text { od 1939 } \\
\text { do 1989 }\end{array}$ & $\begin{array}{c}\text { od 1990 } \\
\text { do 2011 }\end{array}$ & ogółem & $\begin{array}{c}\text { w tym } \\
\text { dziełach } \\
\text { zebranych }\end{array}$ \\
\hline $\begin{array}{l}\text { Prawo dziecka do } \\
\text { Szacunku }\end{array}$ & - & 1 & 9 & 5 & 15 & 7 \\
\hline Refleksje & - & 1 & - & - & 1 & 1 \\
\hline
\end{tabular}

Źródło: opracowanie własne na podstawie: Janusz Korczak. Bibliografia 1896-1942, pod red. A. Lewina, Heinsberg 1985; Janusz Korczak. Bibliografia publikacji Janusza Korczaka i o Januszu Korczaku w Polsce 1943-1987, pod red. A. Lewina, Heinsberg 1988; „Przewodnik Bibliograficzny” za lata 1988-2011; Narodowy Uniwersalny Katalog Biblioteczny; Katalog Rozproszony Bibliotek Polskich; „Polska Bibliografia Literacka” 1988-2000 (wersja elektroniczna).

W dorobku piśmienniczym J. Korczaka znajduje się szereg artykułów o tematyce pedagogicznej, które w formie książkowej publikowano dopiero w okresie powojennym w postaci różnego rodzaju wyborów. Ukazało się kilka tomów zawierających krótkie teksty lub wyjątki z jego twórczości: Myśli (Warszawa 1987), Myśl pedagogiczna Janusza Korczaka: nowe źródła (Warszawa 1983) czy Listy i rozmyślania palestyńskie (Warszawa 1999). Wszystkie te opracowania miały jak do tej pory tylko jedno wydanie, opatrzone szczegółowym komentarzem edytorskim. Warto też wspomnieć, że autor Prawideł życia był współtwórcą kilku drobnych dzieł opisujących funkcjonowanie prowadzonych przez niego domów dziecka. Janusz Korczak napisał również wstęp do zbioru dziecięcych opowiadań zamieszczonych w tomie Wspomnienia z maleńkości dzieci «Naszego Domu» w Pruszkowie (Warszawa 1924) ${ }^{42}$. Jego doświadczenie pedagogiczne oraz talent literacki wykorzystano kilkakrotnie przy redakcji przedwojennych podręczników szkolnych do języka polskiego.

${ }^{42}$ Warto zauważyć, że aktywność literacka J. Korczaka przejawiała się także w pobudzaniu talentów twórczych jego wychowanków, którym umożliwiał publikację własnych utworów na łamach czasopism wydawanych przez prowadzone przez niego sierocińce oraz na łamach „Małego Przeglądu”. Por. M. Ciesielska, W kręgu mistrza. Próby pisarskie bursistów domu sierot Janusza Korczaka, [w:] Korczakowskie dialogi, pod red. J. Bińczyckiej, Warszawa 1999, s. 72-89. 
Obszerne zbiory dzieł J. Korczaka pojawiły się dopiero w okresie powojennym i stanowiły dowód na żywą recepcję jego myśli. Chronologicznie najwcześniej, bo w latach 1957-1958, ukazał się czterotomowy Wybór pism wydany przez „Naszą Księgarnię” pod redakcją Danuty Stępniewskiej ze wstępem Igora Newerlego. Po raz pierwszy zamieszczono tu zachowany w odpisach pamiętnik J. Korczaka z getta ${ }^{43}$. Stosując porządek chronologiczny, w pierwszym tomie opublikowano utwory najwcześniejsze - czwarty zakończono wspomnianym dziennikiem z ostatnich dni życia J. Korczaka. Niemal równolegle w Państwowych Zakładach Wydawnictw Szkolnych (dalej: PZWS) ukazała się dwutomowa edycja Wyboru pism pedagogicznych prezentująca kanon tekstów o wychowaniu. Znalazł się tu również rozdział z powieści Dziecko salonu traktujący o lekcji gramatyki. Posłowie omawiające ostatnie lata życia J. Korczaka napisała Zofia Szymańska, która przedstawiła własne doświadczenia ze współpracy ze Starym Doktorem. Swoistym uzupełnieniem był przygotowany przez Instytut Wydawniczy „Nasza Księgarnia” w 1983 r. tom zawierający nowy wybór artykułów poświęconych myśli pedagogicznej J. Korczaka ${ }^{44}$. Inne dwa wydania dzieł zebranych firmowanych przez to samo wydawnictwo ukazały się również $w$ formie czterotomowej w latach 70. i 80. Ich pojawienie się było pokłosiem prac związanych z Rokiem Korczakowskim. Zawierały w głównej mierze teksty publicystyczne ${ }^{45}$ uporządkowane w układzie tematycznym wyznaczonym przez tytuły poszczególnych tomów ${ }^{46}$. Wstęp do tej edycji przygotował wybitny znawca życia i twórczości J. Korczaka, jego przedwojenny współpracownik, nieżyjący już profesor A. Lewin, a kierowane przez niego grono redakcyjne opracowało szczegółowe przypisy umiejscawiające poszczególne utwory w odpowiednim kontekście procesu historycznoliterackiego ${ }^{47}$. W 1978 r.,

43 Teksty pozostałych utworów przytaczano zazwyczaj zgodnie z ostatnimi wydaniami przedwojennymi i zaopatrywano w obszerne przypisy źródłowe i komentarze.

${ }^{44}$ Myśl pedagogiczna Janusza Korczaka, pod red. A. Lewina, Warszawa 1983. Znalazły się tu teksty w układzie chronologicznym pochodzące m.in. z założonego przez Korczaka „Tygodnika Domu Sierot”, jak również wiele drobnych artykułów drukowanych w rozmaitych tytułach prasy przedwojennej.

${ }^{45}$ W tym dłuższe rozprawy, takie jak: Prawo dziecka do szacunku, Jak kochać dziecko, Dziecko w rodzinie, Internat, Kolonie letnie, Dom sierot, Prawidła życia.

${ }^{46}$ Wielka synteza dziecka - oto co mi się śniło, Praktyka to moje życie, Otwórzmy wrota szkoły szeroko, Jestem człowiekiem samotnej drogi.

47 W latach 1984-1986 ukazało się drugie wydanie niniejszego zbioru, pod wzglę- 
niejako na marginesie tej monumentalnej edycji, oddano do druku jednotomowy zbiór oryginalnie zilustrowany przez Małgorzatę Różańską jesiennymi impresjami liści, zawierający fragmenty dłuższych utworów, m.in. Dziecko salonu, Mośki, Joski i Srule czy Józki, Jaśki i Franki. W krótkim posłowiu Kazimierz Dębnicki stwierdził, że zamieszczone „fragmenty zostały w ten sposób dobrane, aby Czytelnikowi ukazać drogę życiową Korczaka, jego decyzję oddania się sprawom dziecka" ${ }^{48}$. Publikowane w tym okresie kolejne zbiory tekstów miały charakter istotnych przyczynków rozwijających istniejącą bibliografię podmiotu. Niewielki tomik Myśli opatrzony wstępem Hanny Kirchner przybliżył czytelnikom wybór cytatów i aforyzmów pochodzących głównie z pism ulotnych J. Korczaka. Zamieszczono w nim pierwszy drukowany fragment Listów do Józefa Arnona pochodzący z rękopisu będącego w posiadaniu Zakładu Korczakowskiego Instytutu Badań Pedagogicznych ${ }^{49}$. Cennym historycznie zbiorem były Listy i rozmyślania palestyńskie (Warszawa 1999). Zaprezentowano tu korespondencję J. Korczaka z kilkunastoma znajomymi z Izraela, w tym ze wspomnianym już J. Arnonem, autorem kilku publikacji poświęconych jego życiu. Drugą częścią niniejszego opracowania były notatki H. Goldszmita sporządzane w trakcie podróży do Palestyny oraz związane tematycznie z tym wydarzeniem późniejsze odczyty. Uwagę zwraca nader staranne opracowanie edytorskie wymienionych tekstów (wstęp autorstwa Bożeny Wojnowskiej, biogramy osób, do których jest adresowana korespondencja, obszerne przypisy). Ciekawym przykładem syntezy wykorzystującej bogatą literaturę podmiotu i przedmiotu była wydana w Warszawie w 1978 r. praca Stefana Wołoszyna Korczak, w której oprócz ukazania sylwetki pisarza i przedstawienia panoramy jego poglądów na wychowanie zamieszczono liczne fragmenty jego dzieł (w całości jedynie manifest Prawo dziecka do szacunku). Obszerne cytaty z utworów J. Korczaka dość często pojawiały się w literaturze dotyczącej pedagogiki i psychologii dziecięcej. Najobszerniejszym przedsięwzięciem prezentującym twórczość Starego Doktora są wydawane od dwudziestu lat monumentalne Dzieła zebrane pod redakcją Hanny

dem edytorskim niemal identyczne z pierwszym (mimo pewnych zmian, które nastąpiły w kolegium redakcyjnym).

${ }^{48}$ K. Dębnicki, Posłowie, [w:] J. Korczak, Fragmenty utworów, Warszawa 1978, s. 240.

49 J. Korczak, Myśli, Warszawa 1987, s. 47. 
Kirchner, Aleksandra Lewina, Stefana Wołoszyna i Marty Ciesielskiej. Z planowanych szesnastu tomów do tej pory ukazało się trzynaście, przy czym niektóre z tak wydzielonych części zostały umieszczone w kilku oddzielnych woluminach. Oprócz zachowanych archiwaliów autorzy kompilacji zaprezentowali także fragmenty odtworzone na podstawie różnorakich odpisów, w tym teksty mogące budzić pewne wątpliwości co do ich autorstwa, jak np. młodzieńczy dramat Śleboda ${ }^{50}$. Poszczególne tomy były przygotowywane w kooperacji przez wydawnictwa Latona i Czytelnik, ostatnie zaś zostały wydane przez Instytut Badań Literackich PAN. Tej pracy patronowała Fundacja Janusza Korczaka, a w jej edycję włączyło się szereg instytucji, np. Muzeum Historyczne m.st. Warszawy czy Międzynarodowe Stowarzyszenie im. Janusza Korczaka. Finalizację tego cennego przedsięwzięcia utrudniają problemy finansowe i promocyjne, czego wynikiem jest znaczne opóźnianie w czasie ukazania się poszczególnych tomów w stosunku do pierwotnych zamierzeń.

Istotnym elementem spuścizny wydawniczej J. Korczaka były opublikowane w Polsce przedwojennej książki tłumaczone na język jidysz. Już w 1914 r. pojawił się niewielki tom Minjaturn stanowiący wybór najważniejszych tekstów ze zbioru Koszałki opałki. Podobnie jak polski oryginał, zawierał dwa podpisy - „Janusz Korczak” oraz wcześniejszy, nawiązujący do autentycznego imienia, „Hen-ryk”. Pozycja ta w tłumaczeniu L. Goldberga ukazała się w firmie Lewin-Epstein mającej swą siedzibę w Warszawie. Autorem wstępu był Israel Izydor Eliashev, znany też pod pseudonimem Baal Machszowes, urodzony na Litwie krytyk literacki, syjonista i tłumacz prac Teodora Herzla ${ }^{51}$. W latach 20. wyraźnym zainteresowaniem oficyn wydawniczych cieszyła się powieść Jośki, Moski i Srule, wydana w języku jidysz po raz pierwszy we fragmencie pod tytułem In dorf Michajlovka (We wsi Michajłowka) ${ }^{52}$, a następnie już jako całe dzieło Mojšelekh, Joselekh, Sruliklekh w tłumaczeniu żydowskiego pisarza Jechoszui Perlego ${ }^{53}$. Ponadto fragmenty tej książki były też publikowane w wypisach szkolnych służących nauce języka jidysz.

50 Tenże, Dzieła zebrane. Pisma rozproszone. Listy (1913-1939), t. 14, vol. 2, Warszawa 2008, s. 421-423.

51 J. Nemtsov, Die Neue Jüdische Schule in der Musik, Wiesbaden 2004, s. 80.

52 J. Korczak, In dorf Michajlovka, Wydawnictwo A. Gitlin, Warszawa 1921, s. 37.

53 Tenże, Mojšelekh, Joselekh, Sruliklekh, Diagt, Warszawa, 1922, s. 137. 


\section{Oficyny wydawnicze i miejsca wydań}

W swoim Pamiętniku pisanym w warszawskim getcie J. Korczak odnotował: „Kocham Wisłę warszawską i oderwany od Warszawy odczuwam żrącą tęsknotę. Warszawa jest moja i ja jestem jej. Powiem więcej: jestem nią" ${ }^{54}$. Tak więc nic dziwnego, że przeważająca część utworów Starego Doktora ukazała się właśnie w stolicy. Rzecz ciekawa, że za jego życia ani jedna książka (pomijając oczywiście wersje tłumaczone na języki rosyjski, czeski, niemiecki, hebrajski czy esperanto) nie ukazała się poza Warszawą (tabela 4). Dopiero po 1939 r. dzieła J. Korczaka wydawano w innych ośrodkach, takich jak Kraków, Poznań (oraz Jerozolima czy Glasgow w przypadku edycji emigracyjnych w języku polskim). Na większą skalę jego książki zaczęły ukazywać się poza Warszawą dopiero po zmianach ustrojowych w 1989 r. (tabela 4). Charakterystycznym zjawiskiem stało się wówczas rozproszenie działalności edytorskiej.

Tabela 4. Ośrodki, w których ukazała się największa liczba dzieł Janusza Korczaka $^{55}$

\begin{tabular}{|l|c|c|c|c|c|}
\hline \multirow{2}{*}{ Miasto } & \multicolumn{5}{|c|}{ Liczba wydań } \\
\cline { 2 - 6 } & przed 1918 & $1918-1939$ & $1939-1989$ & po 1989 & ogółem \\
\hline Warszawa & 11 & 46 & 66 & 43 & 166 \\
\hline Kraków & - & - & 3 & 24 & 27 \\
\hline Wrocław & - & - & - & 9 & 9 \\
\hline Poznań & - & - & 1 & 6 & 7 \\
\hline Bielsko-Biała & - & - & - & 4 & 4 \\
\hline Łódź & - & - & - & 3 & 3 \\
\hline Białystok & - & - & - & 3 & 3 \\
\hline
\end{tabular}

Źródło: opracowanie własne na podstawie: Janusz Korczak. Bibliografia 1896-1942, pod red. A. Lewina, Heinsberg 1985; Janusz Korczak. Bibliografia publikacji Janusza Korczaka i o Januszu Korczaku w Polsce 1943-1987, pod red. A. Lewina, Heinsberg 1988; „Przewodnik Bibliograficzny” za lata 1988-2011;

54 Tenże, Pamiętnik, [w:] Pisma wybrane, t. 4, Warszawa 1986, s. 337.

55 W tabeli nie uwzględniono miejscowości, w których wydano jedną lub dwie książki J. Korczaka. 
Narodowy Uniwersalny Katalog Biblioteczny; Katalog Rozproszony Bibliotek Polskich; „Polska Bibliografia Literacka” 1988-2000 (wersja elektroniczna).

Do tej pory edycją spuścizny literackiej J. Korczaka zajęło się przeszło 50 podmiotów (tabela 5). Historię obecności dzieł Starego Doktora na polskim rynku wydawniczym można podzielić na cztery okresy. Przed 1918 r. najwięcej pozycji ukazało się w firmie Centnerszwer i spółka, która po przekształceniach własnościowych stała się częścią Towarzystwa Wydawniczego Jakuba Mortkowicza. Do wybuchu II wojny światowej firma ta zajmowała niemal monopolistyczną pozycję w zakresie edycji dzieł J. Korczaka (pojedyncze utwory ukazywały się w mniejszych wydawnictwach związanych głównie z organizacjami społecznymi i kulturą Żydów polskich). Warto zauważyć, że nierzadko równolegle są podawane dwa miejsca wydania ze względu na to, że firma J. Mortkowicza działała aktywnie zarówno w Warszawie, jak i w Krakowie. Niektóre egzemplarze dzieł korczakowskich przed 1939 r. były tłoczone w krakowskich drukarniach W. L. Anczyca czy Napoleona Telza ${ }^{56}$. Podobnie wcześniejszy wydawca J. Korczaka, firma Centnerszwer i spółka, działał w kooperacji z lwowską księgarnią H. Altenberga, co także było niekiedy odnotowywane na stronie tytułowej ${ }^{57}$. W Polsce Ludowej zdecydowana większość dzieł J. Korczaka została wydana w stolicy (tabela 4), co wynikało nie tyle z oczywistych związków pedagoga z Warszawą, ile z centralizacji prowadzonej w tym okresie działalności wydawniczej. Poza miastem stołecznym ukazały się wówczas tylko cztery pozycje. Bezpośrednio po wojnie w Krakowie przygotowano do druku dwa wydania Bankructwa małego Dżeka w reaktywowanym na krótko po 1945 r. wydawnictwie J. Mortkowicza (pod nazwą T. Gieszczykiewicz - J. Mortkowicz), które prowadzili spadkobiercy słynnego księgarza. Kilka innych dzieł sygnowanych przez tę firmę powstało w okresie, kiedy jej główna siedziba znalazła się już w odbudowywanej Warszawie.

Kolejne pozastołeczne edycje pojawiły się dopiero w latach 80 . w krakowskim Wydawnictwie Literackim oraz w Wydawnictwie Poznańskim. Ukazały się tu pierwsze powojenne wydania takich utworów,

${ }^{56}$ Na przykład Kiedy znów będę mały (Warszawa 1925) albo Feralny tydzień (Warszawa 1927).

57 Por. J. Korczak, Mośki, Joski i Srule, Warszawa 1910. 
jak Dziecko salonu i Pamiętnik. Największym powojennym wydawcą dzieł J. Korczaka był związany przede wszystkim z książką i prasą dla dzieci i młodzieży Instytut Wydawniczy „Nasza Księgarnia” (tabela 5). Rzecz ciekawa, że Momenty wychowawcze J. Korczaka ukazały się w tej oficynie już w 1924 r., a więc jeszcze za życia autora. Warto zauważyć, że w Polsce Ludowej znakiem „Naszej Księgarni” sygnowano nie tylko popularne utwory dla najmłodszych, ale również pierwsze edycje dzieł zebranych, w tym tomy zawierające prace pedagogiczne. Kilka dzieł o takiej tematyce przygotowała w latach 40. Spółdzielnia Wydawnicza „Książka”, a w latach 50. PZWS.

Pod koniec lat 70. Krajowa Agencja Wydawnicza (dalej: KAW), wchodząca w skład koncernu RSW „Prasa - Książka - Ruch”, wznowiła dwa utwory beletrystyczne Bankructwo małego Dżeka (1979 r.) i Józki, Jaśki i Franki (1985 r.). Pretekstem do wydania pierwszej z tych pozycji był obchodzony w 1979 r. Międzynarodowy Dzień Dziecka. Jeszcze po przemianach ustrojowych białostocka filia KAW-u kontynuowała popularyzację prozy J. Korczaka, wydając w latach 90. najsłynniejszą powieść dziecięcą - Król Maciuś Pierwszy. Pod koniec PRL pojedyncze edycje ukazały się także w Państwowym Instytucie Wydawniczym (niewielki zbiorek aforyzmów) oraz w Wydawnictwie Pelikan (Prawidła życia z ilustracjami Szymona Kobylińskiego).

Po 1989 r. spuścizna J. Korczaka wzbudziła uzasadnione zainteresowanie dużej liczby oficyn. Mimo, że większość wydań nadal ukazywała się w stolicy, to jednak pojawiły się też nowe ośrodki, takie jak Bielsko-Biała, Łódź czy Białystok (tabela 4). Na uwagę zasługuje londyńska edycja wydawnictwa Puls Król Maciuś na wyspie bezludnej z 1996 r. w polskiej wersji językowej, przeznaczona nie tylko dla brytyjskiej Polonii, ale także rozpowszechniana w kraju. Również w tym okresie pojawiła się specjalizacja polegająca na tym, że niektóre firmy koncentrowały swą uwagę na utworach dla dzieci i młodzieży (np. Zielona Sowa, Beskidzka Oficyna Wydawnicza), inne zaś zajęły się propagowaniem twórczości adresowanej do dorosłego odbiorcy (np. Jacek Santorski). Najwięcej pojedynczych woluminów ukazało się w tym okresie w wydawnictwie Czytelnik/Latona (tabela 5), które podjęło się opracowania całej spuścizny literackiej J. Korczaka w postaci edycji Dzieł zebranych. W ostatnich latach dość licznie były wydawane utwory dziecięce, zwłaszcza w krakowskiej oficynie Zielona Sowa. 
Tabela 5. Najaktywniejsi wydawcy utworów Janusza Korczaka ${ }^{58}$

\begin{tabular}{|l|c|c|c|c|c|}
\hline \multirow{2}{*}{ Oficyna wydawnicza } & \multicolumn{5}{|c|}{ Liczba wydań } \\
\cline { 2 - 6 } & $\begin{array}{c}\text { przed } \\
1918\end{array}$ & $1918-1939$ & $1939-1989$ & po 1989 & ogółem \\
\hline „Nasza Księgarnia” & - & 1 & 47 & - & 48 \\
\hline TW J. Mortkowicz & - & 37 & 6 & - & 43 \\
\hline Czytelnik/Latona & - & - & - & 15 & 15 \\
\hline Zielona Sowa & - & - & - & 13 & 13 \\
\hline Greg & - & - & - & 9 & 9 \\
\hline Siedmioróg & - & - & - & 9 & 9 \\
\hline PZWS & - & - & 7 & - & 7 \\
\hline Jacek Santorski & - & - & - & 6 & 6 \\
\hline IBL PAN & - & - & - & 5 & 5 \\
\hline SW „Książka” & - & 1 & 4 & - & 5 \\
\hline Centnerszwer i s-ka & 4 & - & - & - & 4 \\
\hline Beskidzka Oficyna & - & - & - & 3 & 3 \\
Wyd. & - & - & 2 & 1 & 3 \\
\hline KAW & - & - & - & - & 3 \\
\hline Księgarnia Powszechna & 3 & - & 3 & - & 3 \\
\hline Ministerstwo WRiOP & - & - & - & 3 & 3 \\
\hline WAB & - & - & - & & \\
\hline
\end{tabular}

Źródło: opracowanie własne na podstawie: Janusz Korczak. Bibliografia 1896-1942, pod red. A. Lewina, Heinsberg 1985; Janusz Korczak. Bibliografia publikacji Janusza Korczaka i o Januszu Korczaku w Polsce 1943-1987, pod red. A. Lewina, Heinsberg 1988; „Przewodnik Bibliograficzny” za lata 1988-2011; Narodowy Uniwersalny Katalog Biblioteczny; Katalog Rozproszony Bibliotek Polskich; „Polska Bibliografia Literacka” 1988-2000 (wersja elektroniczna dostępna w Internecie).

${ }^{58}$ W tabeli nie uwzględniono kilkudziesięciu oficyn, które edytowały jedną lub dwie książki. 


\section{Serie, ilustratorzy, przedmowy i postowia}

Oprócz zbiorczych publikacji prezentujących całą spuściznę H. Goldszmita, duża część pojedynczych utworów była wydawana przez poszczególne podmioty w ramach większych serii. Już w okresie przedwojennym firma J. Mortkowicza uznawała za istotne poinformowanie czytelników o spisie prac J. Korczaka, które ukazały się nakładem tej oficyny ${ }^{59}$. Tym samym przy dość jednolitej szacie graficznej kolejnych pozycji można mówić o próbie stworzenia wielotomowej nieformalnej serii dzieł J. Korczaka. Równocześnie przygotowana przez to wydawnictwo w $1927 \mathrm{r}$. powieść Dziecko salonu weszła w skład „Biblioteki Beletrystycznej Towarzystwa Wydawniczego", prezentującej zarówno nowe utwory polskich autorów, jak i te „starsze, dawno wyczerpane a zawsze piękne i niezapomniane" dzieła dawnej i współczesnej literatury obcej" ${ }^{\prime}$. W międzywydawniczej serii „Biblioteka Zrzeszenia Nauczycielstwa Polskich Szkół Początkowych" ukazały się w dwudziestoleciu międzywojennym dwie prace pedagogiczne: w 1919 r. Momenty wychowawcze, a dwa lata później broszura $O$ gazetce szkolnej. Warto też wspomnieć o serii zainicjowanej przez wydawnictwo Judaica przy udziale syjonistycznego funduszu Keren Kajemet Leisrael „Biblioteka Palestyńska dla Dzieci”, w której J. Korczak wydał Ludzie sq dobrzy i Trzy wyprawy Herszka. Co ciekawe, książki te były rozdawane jako nagroda dla czytelników „Małego Przeglądu". Dylogia o królu Maciusiu Pierwszym weszła w skład wydawanej na obczyźnie serii „Szkolna Biblioteczka na Wschodzie” opracowanej pod redakcją doktora Łukasza Kurdybachy, prezentującej około 200 tytułów literatury polskiej i powszechnej przeznaczonej dla szkół polskojęzycznych w Palestynie. Po II wojnie światowej utwory J. Korczaka także często wchodziły w skład różnych serii. Warto zauważyć, że dzieła pedagogiczne ukazujące się pod auspicjami PZWS miały w latach 50. dość jednolitą broszurową formę, różniącą się zazwyczaj jedynie kolorem okładki. Istotnym powodem włączania niektórych utworów J. Korczaka do różnego rodzaju „Biblioteczek...” było zaliczenie

59 Por. J. Korczak, Bezwstydnie krótkie, Warszawa 1926, s. 2; tenże, Józki, Jaśki i Franki, Warszawa 1930, s. 2. Podobne zestawienia umieszczano także w powojennych edycjach tego wydawnictwa: tenże, Król Maciuś Pierwszy, Warszawa 1948, s. 2.

${ }^{60}$ Tenże, Dziecko salonu, Warszawa 1927, s. 242. 
kilku jego powieści w poczet szkolnych lektur. Informację o tym fakcie często umieszczano na okładce i/lub na stronie tytułowej ${ }^{61}$. Tym samym, zwłaszcza w okresie najnowszym, tymi utworami zainteresowało się kilka wydawnictw ${ }^{62}$. W obrębie serii z zakresu literatury młodzieżowej została wydana dwukrotnie powieść Kajtuś Czarodziej, pierwszy raz przez „Naszą Księgarnię” w ramach „Biblioteki Złotego Liścia” (Warszawa 1973) ${ }^{63}$, a potem w wydawnictwie Zielona Sowa (Kraków 2004). Jedynym utworem literackim J. Korczaka, który wszedł w skład kanonu Biblioteki Narodowej, była wydana w 1991 r. w ramach serii dla młodzieży powieść Kiedy znów będę mały.

Już wczesne edycje książek J. Korczaka wzbogacano ilustracjami. W powiastkach z $1902 \mathrm{r}$. pojawiły się pierwsze ryciny anonimowego autora. W pierwodruku powieści Dziecko salonu (Warszawa 1906) zamieszczono na okładce graficzną reprodukcję rysunku autorstwa Lucjana Lewandowskiego. To rozwiązanie zostało powtórzone w dużo późniejszej edycji tego utworu przygotowanej przez Wydawnictwo Literackie (Kraków 1980). Ilustratorami utworów J. Korczaka byli za jego życia Sara Lipszycowa, Adam Ostrowski i Józef Tom. Po II wojnie światowej także starano się zapewnić możliwie najatrakcyjniejszą szatę graficzną, co nie dotyczyło tylko książek dla dzieci i młodzieży, ale również prac pedagogicznych ${ }^{64}$. Do 1989 r. z uwagi na problemy polskiego przemysłu poligraficznego dominowały jednak czarno-białe barwy. Na tym tle pozytywnie wyróżniały się albumowe edycje „Naszej Księgarni” z charakterystycznymi impresjami rysunkowymi Jerzego Srokowskiego (tabela 6).

61 Por. tenże, Bankructwo małego Dżeka, Warszawa 1966; tenże, Józki, Jaśki i Franki, Warszawa 1985 (edycja KAW); tenże, Król Maciuś Pierwszy, Poznań 1996 (edycja GMP).

${ }^{62}$ Na przykład seria „Lektury Szkolne z Opracowaniem” wydawnictwa Kama lub „Kolorowy Świat Lektur” wydawnictwa Philip Wilson.

${ }^{63}$ W stosunku do wcześniejszych wydań z ilustracjami Gabriela Rechowicza edycja ta odznaczała się nieco innym formatem, wzbogaciła się też o charakterystyczną okładkę ze znakiem serii oraz posłowie autorstwa W. Woroszylskiego. J. Korczak, Kajtuś Czarodziej, Warszawa 1973.

64 Niektóre wydania PZWS były ozdobione niewielkimi winietami autorstwa Stanisława Szymańskiego. Ciekawym przedsięwzięciem tego typu były rysunki Szymona Kobylińskiego do edycji Prawideł życia w warszawskiej oficynie Pelikan (1988). 
Tabela 6. Najpopularniejsi ilustratorzy książek Janusza Korczaka

\begin{tabular}{|l|c|c|}
\hline \multicolumn{1}{|c|}{ Ilustrator } & $\begin{array}{c}\text { Liczba } \\
\text { wydań }\end{array}$ & $\begin{array}{c}\text { Okres, w którym ukazywały się } \\
\text { książki J. Korczaka z ilustracjami } \\
\text { wyszczególnionych grafików }\end{array}$ \\
\hline Jerzy Srokowski & 12 & $1955-1991$ \\
\hline Paweł Kołodziejski & 8 & $2001-2007$ \\
\hline Stanisław Szymański & 7 & $1957-1958$ \\
\hline Waldemar Andrzejewski & 6 & $1978-1987$ \\
\hline Józef Tom & 5 & $1913-1946$ \\
\hline Tadeusz Borowski & 4 & $1978-1988$ \\
\hline Artur Łobuś & 4 & $1996-2003$ \\
\hline Marianna Oklejak & 4 & 2011 \\
\hline
\end{tabular}

Źródło: opracowanie własne na podstawie: Janusz Korczak. Bibliografia 1896-1942, pod red. A. Lewina, Heinsberg 1985; Janusz Korczak. Bibliografia publikacji Janusza Korczaka i o Januszu Korczaku w Polsce 1943-1987, pod red. A. Lewina, Heinsberg 1988; „Przewodnik Bibliograficzny” za lata 1988-2011; Narodowy Uniwersalny Katalog Biblioteczny; Katalog Rozproszony Bibliotek Polskich; „Polska Bibliografia Literacka” 1988-2000 (wersja elektroniczna dostępna w Internecie).

Szereg niemal identycznych edycji powieści o królu Maciusiu, różniących się tylko rozmieszczeniem barwnych wkładek z ilustracjami, powstało w latach 50., 60. i 70. W latach 80. pojawiło się nowe wielkoformatowe wydanie z barwnymi wkładkami Waldemara Andrzejewskiego. Rozwój techniki poligraficznej spowodował wzrost częstotliwości ukazywania się edycji ilustrowanych, jednak nawet w ostatnich latach znaczna część książek J. Korczaka nie miała szczególnie rozwiniętej szaty graficznej. Po 1989 r. zwiększyła się liczba nowych wersji ilustratorskich, zazwyczaj poszczególni artyści pracowali dla określonego wydawcy, stąd charakterystyczna stylistyka szaty graficznej właściwa np. dla wydań z wrocławskiego Siedmioroga (Artur Łobuś) czy Beskidzkiej Oficyny Wydawniczej (Aleksandra Dybczak). Warto zaznaczyć, że oprócz ilustracji towarzyszących dziecięcym fabułom niektóre wydania zawierały także elementy dokumentacyjne w postaci zdjęć pisarza, jego wychowanków 
i znajomych oraz fotokopii rozmaitych dokumentów związanych z jego życiem i działalnością.

Dość częstym dodatkiem do książek J. Korczaka były obszerne wstępy lub posłowia zawierające informacje biograficzne lub komentarze filologiczne, w mniej lub bardziej metodyczny sposób przybliżające publikowane utwory. Po raz pierwszy tego typu omówienie pojawiło się w 1944 r. w emigracyjnym wydaniu jerozolimskim Króla Maciusia Pierwszego (autorką była współpracownica J. Korczaka Ada Poznańska). Rzecz ciekawa, że komentarze do wielu edycji utworów Starego Doktora pisały osoby znające go osobiście. Niektóre spośród nich stały się z czasem cenionymi badaczami literatury, pedagogami, poetami czy pisarzami. Do najbardziej znanych należą: I. Newerly, Alicja Szlezakowa, A. Lewin, W. Woroszylski, Krzysztof Teodor Toeplitz czy ks. J. Twardowski.

\section{Podsumowanie}

Spuścizna literacka i naukowa J. Korczaka jest pozornie tematem stosunkowo dobrze poznanym. Aktualność wielu jego poglądów pedagogicznych sprawiła, że dzieła te często analizowano, doszukując się określonych recept wychowawczych. Ich utylitarny charakter powodował, iż mogły być one łatwo cytowane $w$ większych opracowaniach poświęconych tematyce pedagogicznej. Niemniej jednak znamienną rzeczą jest fakt, że popularność dzieł Starego Doktora ma charakter dość jednostronny i ogranicza się najczęściej do kilku najbardziej znanych utworów. W recepcji twórczości J. Korczaka można zauważyć pewne krótkotrwałe mody. Od końca lat 40. do drugiej połowy lat 60. kilkakrotnie wznawiano powieść Bankructwo małego Dżeka. Po 1989 r. szczególną popularnością cieszyła się pierwsza część dylogii o królu Maciusiu Pierwszym. Jednak mimo imponującej liczby edycji książkowych, wersji dźwiękowej, a także powstałej ekranizacji, opowieść ta nie wykazuje cech produktu totalnego ${ }^{65}$. Równocześnie niektóre inne utwory zostały niemal zapomniane, mimo działalności dokumentacyjnej związanej z powstawaniem 16-tomowej edycji Dzieł zebranych. Ta monumentalna praca nie mogła konkurować z szybkimi

${ }^{65}$ Definicję produktu totalnego przedstawił M. Zając w książce Promocja książki dziecięcej, Warszawa 2000, s. 163-164. 
wydaniami komercyjnymi, lecz na jej marginesie powstało kilka interesujących tematycznych antologii grupujących dzieła J. Korczaka pod kątem refleksji historycznej czy filologicznej. Z pewnością popularność niektórych utworów literackich najsłynniejszego polskiego pedagoga wynikała z ich atrakcyjności fabularnej oraz z faktu, że były one oryginalne i pod wieloma względami prekursorskie. Zadecydowała o tym również postawa samego autora, który prezentowane przez siebie poglądy uwiarygodnił swoją działalnością i heroiczną śmiercią.

\section{Books by Janusz Korczak in Polish publishing market}

ABSTRACT: The paper describes the development of the publishing market associated with the literary legacy of Janusz Korczak, since his first self-published book of 1901 to the present time (2011). The analysis includes all self-published printed works released in Poland during this period (also translations into Yiddish published before World War II) and books published abroad in Polish. The article focuses on several aspects related to the published legacy, such as publication of first editions, geographic and institutional reach, periodization and some library science features, for example being a part of a series, the artwork, author's comments and editions. The varied number of editions of individual titles in the period indicates the changing popularity of certain content, which was due to specific editorial policy at the times of socialism in Poland as well as ideological and social changes affecting the reception of J. Korczak's works after 1989.

KEYWORDS: book reception, editorial statistics, editorship, Korczak Janusz. 